\title{
Student's Perception of E-Dictionary Arabic Indonesian in IR 4.0 Era
}

\author{
$1^{\text {st }} R$. Taufiqurrochman ${ }^{1}, 2^{\text {nd }}$ Dewi Nur Suci ${ }^{2}$ \\ \{taufiq@uin-malang.ac.id ${ }^{1}$, dewinursuci@gmail.com² \\ Universitas Islam Negeri Maulana Malik Ibrahim Malang ${ }^{1}$, Institut Agama Islam Negeri Kediri²
}

\begin{abstract}
Dictionaries Arabic-Indonesian take pivotal roles in the learning and teaching process for the teacher and the students of Arabic Education Department to comprehend and interpret the meaning of texts. Firstly, popular with the printed version for Arabic Foreign Language (AFL) classrooms in Indonesia, the Arabic-Indonesian dictionaries have rapidly evolved to be electronic dictionaries that are much widely functioned by the Millennial through websites or mobile applications with online and offline modes. This industrial revolution 4.0, consequently, initiates research problems on how the use of Arabic electronic dictionaries in Indonesian context, what kinds of printed and e-dictionaries students employ and how the positive and negative implications of its utility in AFL classrooms. Under quantitative design by distributing online questionnaire with Google Form to 120 respondents comprising the students majoring Arabic education at Faculty of Tarbiyah and Teacher Training in Maulana Malik Ibrahim State Islamic University of Malang who enroll Shinaat alMu'jam (lexicography) and the teacher of the course, the respondents admit that they have operated e-Arabic-Indonesian dictionaries to assist them in searching the meaning of the text due to the effectiveness, efficiency and variety of related vocabulary. In addition, alMunawwir and Google Translator have received many attentions in AFL classroom. Finally, this research highlights that in the vast growth of e-Arabic-Indonesian dictionaries that have multifunction on the text translating, the teacher and the students should selectively choose the one that has high accuracy of meaning interpretation. By these considerations, the electronic dictionaries are relevant media for blended learning that is being implemented in Islamic Higher Education (IHE) in the 21st century.
\end{abstract}

Keywords: e-Dictionary Arabic Indonesian; Industrial Revolution; e-learning

\section{Introduction}

The Industrial Revolution (IR) 4.0 marked by Cyber Physical Production System (CPPS), Internet of-Things (IoT), Cloud Computing and predictive data analysis has provided new impetus for the educational transformation that encourages the teachers and students to find innovations in instructional classrooms [1]-[5]. These innovations can create new learning ecosystem with appropriate content, pedagogy, media, assessment and management of education that are borderless and independent of time and places. These shifts in education can be in the form of books, libraries, management, and others into e-books, e-libraries, website pages and mobile-based 
applications, for instance Moodle, Edmodo, Google Classrooms and other media that support flipped classrooms or blended classrooms.

Therefore, the higher education should set a curriculum that can strengthen the graduate quality with the future workforce and technologies [2], [6], [7]. One of which is by promoting software applications in the instructional classrooms of Arabic Foreign Language (AFL). In the context of translating first language into foreign language, including Arabic, the students in Indonesia have started to utilize electronic dictionaries rather than printed dictionaries. Similarly in English Foreign Language (EFL) classroom, it is argues that the current growths in digital technologies have shaped students' dictionary ownership and preferences within which the electronic dictionaries have been more vital than that of the paper dictionaries due to its portability, mobility and efficiency [8]-[11].

This switch of conventional learning style to the modern one in foreign language classrooms requires the teachers and the students to have literacy skills in the field of educational technology [12]. Reflected in AFL classrooms, literacy skills deal not only with teaching materials and curriculum development, but also in the aspects of language programming, development models of language device and periodic evaluations to scrutinize the positive and negative aspects of the effect of IR 4.0 in Arabic education. One of literacy skills in Arabic lexicography course is searching for meaning in a dictionary.

Nowadays, a lot of dictionaries have adopted Oxford dictionaries as a Western product to be a role model in designing dictionary, without any exception the Arabic dictionary. However, the father of Arabic lexicographer al Khalil ibn Ahmad al-Farahidi (719-791 A.D.) is famous for envisioning an original and a formal description of Arabic by an accounting for the underlying skeletal structures of Arabic, based on their phonetic features, that are realized in the derivations according to the permitted measures of the language, such as $[\mathrm{k}, \mathrm{t}, \mathrm{b}]$ as a possible structure would have the permutations [k, b, t], [t, k, b], [t, b, k], etc [13].

Another way of paper dictionary of Arabic based on Imel Badi Ya'qub consists of 5 aspects, namely phonetic system (shauthi), letter system (hija'i), literary system (adabi), alphabet system (alfaba'i), and the articulation system (nuthqi).[14] These five systems have been used for several centuries in the field of lexicology-lexicography and implemented in printed versions of Arabic dictionaries before electronic dictionaries have been developed. Each systematics has a special character and way of searching vocabulary, explaining and understanding meanings, and translating it from one language to another. In fact, recent electronic dictionaries and printed versions are mostly different from the traditional versions. After electronic dictionaries were found, the five systems printed versions of the Arabic dictionary system began to be abandoned.

Considering the issue of the technology integration in AFL classrooms of Indonesian context, this research is aimed at revealing the Arabic-Indonesian dictionary ownership and preference of the students majoring Arabic education at Faculty of Tarbiyah and Teacher Training in Maulana Malik Ibrahim State Islamic University of Malang enrolling Shinaat al-Mu'jam (lexicography). Secondly, this research investigates what kinds of dictionary that highly support the students' needs. It is because of the different effectiveness and efficiency of both electronic dictionaries and paper dictionaries that the students favor in Arabic course. A study exemplifies that students at Qassim University tends to choose bilingual dictionaries over monolingual dictionaries particularly when finding meaning of unknown words [15]. The third focus is on the (dis)advantages of the Arabic-Indonesian dictionaries. 
Examining these foci is not only expected to explore the students' abilities to use dictionaries but also how capable the students in measuring the strength and the weakness of dictionaries that suitably proportionate with their needs in translating language and in learning on how to be a professional lexicographer that meets the high demands of society in this fast-changing era. The results of the study on dictionary use by Saudi EFL students at Qassim University show that Saudi students do not take full advantage of the different dictionaries available, and that they are not trained on how to make full use of the dictionaries so that most of them are not aware with the pragmatic aspect of the word, collocations as well as word formation knowledge and just focus on the definition or meaning of a word while neglecting [15].

A dictionary is a book or reference that contains a large number of vocabulary which are generally arranged according to a particular systematics in alphabetical order, or thematically, or other systems according to the purpose of composing a dictionary [16]. A complete and perfect dictionary is a dictionary that is able to collect all of the language vocabulary, equipped with meaning and interpretation of its meaning, providing a word pronunciation system and explaining word derivation, to the example of the use of words in sentences so that users of dictionary can understand each meaning of word in context [17].

Dictionary can serve a lot of purposes especially in providing the definition of words and terms, it can improve students' learning ability, it does not only improve students' proficiency in second language but also helps to increase the command of their mother language and the dictionary can also boost self-learning activity and would motivate the students to read more materials according to their interest [18]. In conjunction with learning Arabic, studies of dictionaries are studied in lexicology and the art of composing dictionaries are studied in lexicography. Lexicology is a part of pure linguistics, while lexicography is part of applied linguistics. Thus, lexicology and lexicography are branches of linguistics as pedagogy-linguistics or language education is also part of applied linguistics [19].

Why are the Arabian late in codifying languages and composing dictionaries? According to Ahmad Amin it is because of three factors, namely the nomadic tradition of the Arab nation, fond of fighting, and prioritizing spoken language rather than written language [10]. Now, in the era of the industrial revolution 4.0, the Arabs also lag behind in the field of composing an electronic dictionary. This is because the direction of digital technology remains in the Western power. Therefore, innovation and new research are related to the development of Arabic dictionaries along with the development of science, science and technology.

Electronic dictionaries as an innovation are dictionaries that can be accessed through electronic devices such as computers, computer networks, cellphones, and so on [22]. Nowadays, electronic devices have developed into digital one that starts leaving analogues system. Databases stored in electronic devices also use Big Data technology and Cloud technology. In addition, almost all dictionary applications have been mobile-based which can be taken anywhere and accessed anytime via a mobile device.

In the past, the researcher divided electronic dictionaries into 3 parts, namely computer software-based dictionaries, website page-based dictionaries, and mobile application softwarebased dictionaries [23]. Recently, almost all electronic dictionary applications can be accessed on all devices, both computers, websites, and mobile applications [24]. One of the most popular electronic dictionaries is Google Translate. This dictionary is not only based on websites, but also in the form of mobile applications that can be accessed via a computer and a smartphone. 
From a systematic aspect, electronic dictionaries are designed so that users can simply type the word they want to know the meaning of, press the enter button, and the meaning of the word directly come up. A research investigating the effectiveness between the electronic dictionaries and paper dictionaries perceived that benefit of electronic pocket dictionaries is the speed with which students can look up entries [15], [25]. Thus, it is different from the printed dictionary version that requires users to learn first the systematics of each dictionary they use. They have to open dictionaries based on the alphabetical order of the derivation or root of the words.

In terms of language, almost all electronic dictionaries today are multi-lingual. Every electronic dictionary produced by developers has been able to translate from one language to several other languages with unlimited amounts of data, while the printed version dictionaries are almost impossible to contain more than 3 languages due to paper limitations. For example, the use of Computer Assisted Translator (CAT), one of translator software can offer ease for translators in translation industry. CAT shares beneficial aspects in refining text consistency and terminological coherence which help to save time by recycling previously translated strings (leveraging) [26].

In terms of content, in explaining the meaning of words, electronic dictionaries not only display text, but also sounds, images and videos so that users become more aware. Therefore, electronic dictionaries are multimedia because they have fulfilled 5 multimedia elements (text, images, sound, video, animation). A research portrays that students used the mobile dictionary mostly in pronunciation, spelling, writing, and most importantly in finding the meaning of new vocabulary. They had fun, and interesting experience in applying this such kind of technology in language learning [27]. This is clearly not possible to be filled by printed versions of conventional dictionaries.

A typical electronic dictionary is operated with battery, lightweight and portable which is designed with a full keyboard in the main unit and a display in the lid, while current high end dictionaries consume more power due to its smartness to display language instruction videos and multimedia language training games because of the design that is equipped with backlit color and touch sensitive displays [25].

\section{Method}

Researchers distributed questionnaires by using Google Form links through WhatsApp applications to 120 respondents. They are 100 students and 20 teachers at the Department of Arabic Language Education, Faculty of Tarbiyah and Teacher Training, Maulana Malik Ibrahim State Islamic University, Malang. These students enroll the Shinaat al-Mu'jam (lexicography) course. This questionnaire contains questions about the Arabic dictionary they use in learning Arabic. 


\section{Results and Discussion}

Of the 120 respondents, 118 people (93\%) state that they own an Arabic dictionary, while 2 people (7\%) claim that they have no Arabic dictionary. The reason they have an Arabic dictionary is because: (1) they need an Arabic dictionary to understand the meaning of the word, (2) It can make them easier to learn Arabic and translate it into Indonesian, (3) Owning an Arabic dictionary is a requirement in the lexicography course by their teacher. The data can be seen in Table 1 .

Table 1. Dictionary Ownership of The Respondents

\begin{tabular}{|c|c|c|}
\hline Dictionary Users & Number & Percentage \\
\hline Have a dictionary & 118 & $98 \%$ \\
\hline Have no a dictionary & 2 & $2 \%$ \\
\hline Total & 120 & $100 \%$ \\
\hline
\end{tabular}

The respondents report that some of them have more than one dictionaries for learning foreign language. The data on the ownership of more than one dictionary are presented in Table 2.

Table 2. Ownership of Dictionary Number

\begin{tabular}{|l|c|c|}
\hline $\begin{array}{l}\text { Number of Owned } \\
\text { Dictionary }\end{array}$ & $\begin{array}{l}\text { Number of } \\
\text { Respondent }\end{array}$ & Percentage \\
\hline 1 Dictionary & 45 & $38 \%$ \\
\hline 2 Dictionaries & 39 & $31 \%$ \\
\hline 3 Dictionaries & 21 & $18 \%$ \\
\hline 4 Dictionaries & 9 & $8 \%$ \\
\hline 5 Dictionaries & 4 & $3 \%$ \\
\hline More 6 Dictionaries & 2 & $2 \%$ \\
\hline Total & 120 & $100 \%$ \\
\hline
\end{tabular}

Because the printed versions of Arabic dictionary are variously published in Indonesia. More students have more than one dictionaries. Data in Table 3 show that al-Munawwir ArabicIndonesian translation has been mostly chosen by the respondents, while the Indonesian-Arabic is in the fifth position. It can indicate that the students tend to learn from second language to the first language.

Table 3. Paper Dictionaries Possessed by The Students

\begin{tabular}{|l|c|c|}
\hline \multicolumn{1}{|c|}{ Paper Dictionary } & Number & Percentage \\
\hline Munawwir Arab-Ind & 88 & $29 \%$ \\
\hline Mahmud Yunus Arab-Ind & 77 & $25 \%$ \\
\hline Arabia Baina Yadaika & 34 & $11 \%$ \\
\hline Al-Ashri Arab-Ind & 22 & $7 \%$ \\
\hline Munawwir Ind-Arab & 16 & $5 \%$ \\
\hline Al-Bisri Arab-Ind Ind-Arab & 15 & $5 \%$ \\
\hline Al-Ashri Ind-Arab & 14 & $5 \%$ \\
\hline Al-Munjid Arab-Arab & 7 & $2 \%$ \\
\hline
\end{tabular}




\begin{tabular}{|l|c|c|}
\hline Al-Kalali Ind-Arab & 6 & $2 \%$ \\
\hline Majmu'at Arabia & 5 & $2 \%$ \\
\hline Mukhtar Shihah Arab-Arab & 4 & $1 \%$ \\
\hline Kamus 3 Bahasa & 4 & $1 \%$ \\
\hline As-Sayuti Ind-Arab & 4 & $1 \%$ \\
\hline Al-Kamil Arab-Ind & 4 & $1 \%$ \\
\hline Ar-Rahman Ind-Arab & 3 & $1 \%$ \\
\hline \multicolumn{1}{|c|}{ Total } & 303 & $100 \%$ \\
\hline
\end{tabular}

Table 3 shows that there are 303 dictionaries of Arabic-Indonesian and Indonesian-Arabic versions that are preferred by the respondents in learning Arabic. Then, this research scrutinizes the best version of printed dictionaries that support the respondents' teaching and learning process. The data are shown in Table 4.

Table 4. Preference of Paper Dictionary

\begin{tabular}{|c|c|c|}
\hline Mostly preferred dictionary & Number & Percentage \\
\hline Munawwir Arab-Ind & 42 & $35 \%$ \\
\hline Al-Ashri Arab-Ind & 29 & $24 \%$ \\
\hline Al-Wasith Arab-Arab & 16 & $13 \%$ \\
\hline Al-Munjid Arab-Arab & 14 & $12 \%$ \\
\hline Mahmud Yunus Arab-Ind & 10 & $8 \%$ \\
\hline Lisan Arab & 4 & $3 \%$ \\
\hline Arabia Baina Yadaika & 3 & $3 \%$ \\
\hline No Answer & 2 & $2 \%$ \\
\hline Total & 120 & $100 \%$ \\
\hline
\end{tabular}

Table 4 presents that dictionary of Munawwir Arabic-Indonesian version is mostly functioned by the respondents. Of 120 respondents, 42 respondents categorize the dictionary of Munawwir Arabic-Indonesian as the best version. It indicates that this dictionary is relevant to use in lexicography course.

Different from paper dictionaries, the questionnaire presents that there are some electronic dictionaries that can be exerted by the respondents. Table 5, 6 and 7 display the range of the electronic dictionary that assists the students to search and interpret meanings. Some include bilingual dictionaries and other involve multilingual dictionaries that can be connected online or offline modes with website-based or software application that are assessable in computer or mobile phone.

Table 5. The Electronic Dictionary (Computer-Application)

\begin{tabular}{|l|c|c|}
\hline $\begin{array}{c}\text { E-Dictionary (Computer } \\
\text { Application) }\end{array}$ & Number & Percentage \\
\hline Golden Al-Wafi Arabic Translator & 4 & $33 \%$ \\
\hline Al-Mufid 1.0 & 2 & $17 \%$ \\
\hline Kamus Bahasa Arab 2.0 & 2 & $17 \%$ \\
\hline Effel's Arabic & 2 & $17 \%$ \\
\hline Arab VerbAce Translation & 2 & $17 \%$ \\
\hline
\end{tabular}




\begin{tabular}{|c|c|c|}
\hline Total & 12 & $100 \%$ \\
\hline
\end{tabular}

Table 5 exemplifies that Golden al-Wafi Arabic Translator as bilingual dictionary becomes mostly selected. This dictionary is available in online website and software installation.

Table 6. The Electronic Dictionary (Website-Based)

\begin{tabular}{|c|c|c|}
\hline $\begin{array}{l}\text { Electronic Dictionary Website- } \\
\text { Based }\end{array}$ & Number & Percentage \\
\hline Google Translate & 12 & $46 \%$ \\
\hline Global Translate & 3 & $12 \%$ \\
\hline 101language.com & 2 & $8 \%$ \\
\hline Ajax Trans & 2 & $8 \%$ \\
\hline All Word & 2 & $8 \%$ \\
\hline Foreign Words & 2 & $8 \%$ \\
\hline ImTranslator & 1 & $4 \%$ \\
\hline Translator Base & 1 & $4 \%$ \\
\hline Word Reference & 1 & $4 \%$ \\
\hline Total & 26 & $100 \%$ \\
\hline
\end{tabular}

Table 7. The Electronic Dictionary (Mobile Phone)

\begin{tabular}{|c|c|c|}
\hline Mobile Phone Dictionary & Number & Percentage \\
\hline Google Translate & 42 & $53 \%$ \\
\hline Indonesia Arabic Translator & 8 & $10 \%$ \\
\hline Offline Dictionaries & 6 & $8 \%$ \\
\hline QuickDic Offline Dictionary & 5 & $6 \%$ \\
\hline English Arabic Transalator & 4 & $5 \%$ \\
\hline English Arabic Dictionary Free & 4 & $5 \%$ \\
\hline Gamoos Arabic English Dict & 4 & $5 \%$ \\
\hline Arabic English Dictionary & 2 & $3 \%$ \\
\hline Arabic English Dictionary Box & 2 & $3 \%$ \\
\hline $\begin{array}{l}\text { Kamus Indonesia Arab Ristek } \\
\text { Muslim }\end{array}$ & 2 & $3 \%$ \\
\hline ArabDict Dictionary & 1 & $1 \%$ \\
\hline Total & 80 & $100 \%$ \\
\hline
\end{tabular}

Based on Table 6 and Table 7, it can be analyzed that the respondents mostly favor Google Translate as a tool for translation. This translation tool needs internet connection to translate word(s), phrase(s), paragraph(s) and document(s).

The reasons the respondents function the electronic dictionary vary: (1) it is easy to find words, (2) it is faster in the search for the meaning of words, (3) it utilizes the functions of smartphones owned, (4) the dictionaries of the printed version are difficult to carry while electronic dictionaries are more practical, (5) the vocabulary in the printed dictionary is relatively incomplete, (6) the electronic dictionary features are more complete and various, (7) the electronic dictionaries are cheaper, even free. 
Identified on how many times the students function the electronic dictionary of ArabicIndonesian or Indonesian-Arabic, 112 respondents $(100 \%)$ claimed to have used electronic dictionaries, both through computers and smartphones; 76 people $(63 \%)$ admitted frequently, 32 people $(27 \%)$ admitted sometimes, and 4 people $(10 \%)$ claimed to rarely use electronic dictionaries.

Table 8. The Frequency On The Use Of Electronic Dictionary

\begin{tabular}{|l|c|c|}
\hline \multicolumn{1}{|c|}{ Use frequency } & Number & Percentage \\
\hline Very frequent & 35 & $29 \%$ \\
\hline Frequent & 48 & $40 \%$ \\
\hline Sometimes & 24 & $20 \%$ \\
\hline Rarely & 11 & $9 \%$ \\
\hline Never Total & 2 & $2 \%$ \\
\hline \multicolumn{2}{|c|}{} \\
\hline \multicolumn{2}{|c|}{} \\
\hline
\end{tabular}

Based on the results, it is found out that electronic dictionaries of Arabic-Indonesian and Indonesian-Arabic have been rapidly developed and utilized in Arabic Foreign Language (AFL) classrooms in Indonesia. Electronic dictionary application developers vary from overseas with large companies of mobile applications, the Indonesia localizers or individuals. This is because the Android-based application is indeed open source, giving anyone the opportunity to compete to create electronic dictionaries [28]. Accordingly, everyone can access the bulk of words in dictionaries either from online or offline connections with any gadgets that are compatible with such electronic dictionaries.

The development of this open source Android-based electronic dictionary in many numbers has provided positive aspect because it is capable of producing many dictionaries with various advantages and features that continue to innovate and creatively modify [10], [22]. However, teachers and students in Arabic education department should meticulously select which electronic dictionaries they have to use in the language instructional classrooms. The vast spread of the application in Playstore is considered lack of meaning or truth validity. The users should have lexicography skills to reproduce certain meanings when translating texts. One of which is by recognizing whether the products are developed by individuals or companies without the linguistics experts in the field of language and research.

The problem of truth accuracy in Arabic electronic dictionaries must be a crucial concern because dictionaries are positioned as learning resources and references for students [10], [22], [27]. It can also improve student's vocabulary mastery [29], [30]. When there is an error in the dictionary contents, then the dictionary misleads its users. Therefore, [31], [32] have promoted the use of Machine Translation (MT) to obtain significant meaning in a text. In [33], there is a wide attention to all the Arab scientists as well as administrators and thinkers to the important nature of Arabic Machine Translation (AMT) by introducing translation machine criteria that consist of completeness, correctness, and stylistic criteria, which were defined in terms of the lexicon, grammar, and the mapping rules. These are intended to measure translation correctness.

When viewed from the features in the application of electronic dictionaries, researchers found a very prompt advance compared to a few years ago. Electronic dictionaries are currently able to translate words, texts, sentences to phrases. Users can choose multiple languages simultaneously. 
By one clicking, they have got their meaning. In addition, the electronic dictionary has been able to translate sounds, listen to translations, voice input and output, copy translations (clipboard), designing attractive graphics, creating artistic color themes, supporting multiple languages in the electronic dictionary [8], [18], [22], [27], [28], [34].

One of the fundamental drawbacks of electronic dictionaries, according to researchers, is the translation of text or sentences from one language to another, including Arabic.[17] According to the results of the research, it is found that the text translation feature in the Arabic electronic dictionary was unable to produce good and correct translations. Researchers found many grammatical errors in the translation of Arabic. Those comprise the translation of single and plural words, the words mudzakkar (masculine) and muannas (feminine), the use of dhomir (pronouns), the words ma'rifat and nakirah, and others.

Furthermore, researchers have not found an electronic dictionary that is able to translate text or sentences properly and correctly so that text translation features in electronic dictionaries can cause a lot of errors for dictionary users. Similarly, the main difficulties faced in English Foreign Language (EFL) classroom are incomplete definitions, lack of credibility on some bilingual edictionaries' developers, and lack of definitions and examples [15], [35]. Regarding to this phenomenon, the majority of students should be critical on the use of electronic dictionaries as a part of technology advance in digital era. It can assist them to learn language independently.

From the hardware aspect, all mobile-based electronic dictionaries can be installed on various brands of smartphones, both cellphones that use Android, Apple, Blackberry, and so on [28]. Among electronic dictionaries, there are dictionaries that need an internet connection (online), some of which can be deployed without an internet connection (offline). In addition, a Wifi or Hotspot connection supports users for free electronic dictionaries without spending internet data payment. This ease and flexibility encourage students to use electronic dictionaries through smartphones in their hands.

From the obtained data, there were several printed dictionaries in Indonesia which began to be developed into electronic versions such as Indonesian-Arabic al-Munawwir dictionary and ArabicIndonesian dictionary. This fact shows that the enhancement of Arabic dictionaries in Indonesia has followed the trend of digital technology. Therefore, the study of dictionaries (lexicography) in the Arabic education curriculum should not be limited to the analysis and evolvement of printed version dictionaries, but also should lead to the current trends of digital-based electronic dictionaries and mobile applications.

\section{Conclusion}

The use of electronic dictionaries in Arabic Foreign Language (AFL) classrooms have attracted more interests than that of paper dictionaries due to its effectives and efficiency of use. This fact supports the demand of students needs in this fast changing era because they are categorized as digital natives who are able to operate technology and other social media for language instruction [36]-[38]. Electronic dictionaries are more accessible, various, complete, 
inexpensive, easily updated and revised. Besides, it and can be developed by anyone and at any time, both by companies and individuals.

Systematics in the preparation of Arabic electronic dictionaries is much better and is not limited to the five-traditional systematics that have been set by classical Arabic lexicologists. In addition, the text translation feature in the electronic dictionary is still unable to translate text correctly according to Arabic grammatical rules.

Therefore, the lecture material in the Arabic lexicology-lexicology course needs to be developed by including teaching materials that examine electronic dictionaries. Educational institutions or language institutions, both public and private, need to produce qualified and credible Arabic electronic dictionaries so that they can be used by the educational users (lecturers, students, researchers, and the community). In so doing, they can find a highly recommended and correct electronic dictionary application in Arabic translation.

Acknowledgment. The researchers would like to thank to Faculty of Tarbiyah and Teacher Training Universitas Islam Negeri Maulana Malik Ibrahim Malang-East Java, Indonesia for facilitating the researchers in conducting this research.

This paper in conjuction with the $3^{\text {rd }}$ International Conference of Islamic Education (ICIED) who have shared more constructive feedbacks on this research.

\section{Reference}

[1] D. B. Abdullah, M. Y. Abdullah, and M. A. M. Salleh, "A Review on the Concept of Fourth Industrial Revolution and the Government's Initiatives to Promote It Among Youths in Malaysia,” p. 8, 2017.

[2] H. Van Thai and M. A. L. T. K. Anh, "The 4.0 Industrial Revolution Affecting Higher Education Organizations' Operation in Vietnam," Int J Manag Technol, vol. 4, no. 2, pp. 1-12, 2017.

[3] Y. Liao, E. R. Loures, F. Deschamps, G. Brezinski, and A. Venâncio, "The impact of the fourth industrial revolution: a cross-country/region comparison," Production, vol. 28, no. 0, pp. 1-18, 2018.

[4] J. Sun, M. Gao, Q. Wang, M. Jiang, X. Zhang, and R. Schmitt, "Smart Services for Enhancing Personal Competence in Industrie 4.0 Digital Factory,” Sci J Logist, vol. 14, no. 1, pp. 51-57, 2018.

[5] G. Schuh, T. Gartzen, T. Rodenhauser, and A. Marks, "Promoting Work-based Learning through INDUSTRY 4.0," Procedia CIRP, vol. 32, pp. 82-87, 2015.

[6] F. Henard and S. Leprince-Ringuet, "The path to quality teaching in higher education," Paris OCED Publ, 2008.

[7] C. Huguet, J. Pearse, L. F. Noè, N. Castillo Ruiz, D. Valencia, A. Jimenez Heredia, and M. A. Patiño Avedaño, "Use of emerging technologies in flipped classes," in Proceedings of the 3rd International Conference on Higher Education Advances, 2017.

[8] M. Şevik, "University Prep-school EFL Learners' Dictionary Ownership and Preferences," Procedia - Soc Behav Sci, vol. 158, pp. 226-232, Dec. 2014.

[9] R. Taufiqurrochman, Kamus Kedokteran Nuria Indonesia-Arab Arab-Indonesia. Yogyakarta: Ar Ruzz Media, 2014.

[10] I. Agustina and M. Murtopo, "The Development of Android Based Dictionary For Graphic Technique,”J ARBITRER, vol. 4, no. 2, p. 93, Sep. 2017. 
[11] A. Mahmoud, "Should Dictionaries be Used in Translation Tests and Examinations?," English Lang Teach, vol. 10, no. 3, p. 171, Feb. 2017.

[12] X. Chen, "Evaluating Language-learning Mobile Apps for Second-language Learners," J Educ Technol Dev Exch, vol. 9, Dec. 2016.

[13] S. I. Sara, "The formal approach of Pal-Khalīl to Arabic lexicography," WORD, vol. 51, no. 1, pp. 21-39, Apr. 2000.

[14] Y. Imel, Al-Ma'ajim Al-Lughawiyyah Al-'Arabiyyah. Bairut: Dar al Ilm lil Malayin, 1981.

[15] A. Hamouda, "A Study of Dictionary Use by Saudi EFL Students at Qassim University,” Stud English Lang Teach, vol. 1, no. 1, p. 227, Feb. 2013.

[16] A. Al-Batily, Al-Ma'ajim Al-Lughawiyyah wa Thuruq Tartibihaa. Riyadh: Dar Al-Rayah, 1992.

[17] R. Taufiqurrochman, "Tashniif al-Ma'ajim al-'Arabiyyah wa Tathwiiruhaa fii Indonesia," Universitas Islam Negeri Maulana Malik Ibrahim Malang, 2014.

[18] C. A. M. B. C. Omar and H. B. A. M. Dahan, "The Development of E-Dictionary for the Use with Maharah Al-Qiraah Textbook at a Matriculation Centre in a University in Malaysia," Turkish Online J Educ Technol, vol. 10, no. 3, pp. 255-264, 2011.

[19] A. M. Umar, Shina'at al-Mu'jam al-Hadits. Baerut: ‘Alam el-Kutub, 1998.

[20] Munir, Kurikulum Berbasis Teknologi Informasi dan Komunikasi. Bandung: Alfabeta, 2010.

[21] A. Al-Qasimy, Ilm Lughah wa Shina'ah al-Mu'jam. Riyadh: King Saud University, 1991.

[22] J. Ronald and S. Ozawa, "The Electronic Dictionary in the Language Classroom: The Views of Language Learners and Teacher." [Online]. Available: https://www.researchgate.net/publication/266411981_The_Electronic_Dictionary_in_the_Language_Clas sroom_The_Views_of_Language_Learners_and_Teachers.

[23] R. Taufiqurrochman, “Al-Maa'jim al-'Arabiyyah al-Iliktroniyah wa istikhdamuha,” Abjadia, vol. 1, no. 2, pp. 131-139, 2016.

[24] H. Sobri, Tiknulujia al-Ma'lumaat wa Dauruhaa fii Ta'ziiz Musyarakah al-'Amiliin. Oman: Ibar, 2002 .

[25] H.-L. Jian, F. E. Sandnes, K. M. Y. Law, Y.-P. Huang, and Y.-M. Huang, "The role of electronic pocket dictionaries as an English learning tool among Chinese students: Electronic pocket dictionaries," J Comput Assist Learn, vol. 25, no. 6, pp. 503-514, Nov. 2009.

[26] A. F. Costales, "The role of Computer-Assisted Translation in the field of software localization," Eval Transl Technol, vol. 8, pp. 179-194, 2009.

[27] K. A. Barham, "The Use of Electronic Dictionary in the Language Classroom: The Views of Language Learners," 2017.

[28] R. Dashtestani, "EFL teachers' and students' perspectives on the use of electronic dictionaries for learning English,” CALL-EJ, vol. 14, no. 2, pp. 51-65, 2013.

[29] R. de los M. R. Ortega and P. V. González, "University Students' Use of Electronic Dictionaries in Hidalgo, Mexico,” MEXTESOL J, vol. 40, no. 4, pp. 1-10, 2016.

[30] M. Rezaei and M. Davoudi, "The Influence of Electronic Dictionaries on Vocabulary Knowledge Extension,” J Educ Learn, vol. 5, no. 3, pp. 139-148, 2016.

[31] S. Hampshire, "Translation and the Internet: Evaluating the Quality of Free Online Machine Translators," Quaderns, vol. 17, pp. 197-209, 2010.

[32] K. A. Kadhim, L. S. Habeeb, and A. A. Sapar, "An Evaluation of Online Machine Translation of Arabic into English News Headlines: Implications on Students' Learning Purposes," Turkish Online J Educ Technol, vol. 12, no. 2, p. 12, 2013.

[33] R. Zantout and A. Guessoum, "Arabic Machine Translation: A Strategic Choice for the Arab World," J King Saud Univ - Comput Inf Sci, vol. 12, pp. 117-144, 2000. 
[34] D. I. Alizadeh, "Medical Students' Perception of Using Electronic Learning Tools in an ESP Program,” Int J Res English Educ, vol. 3, no. 1, pp. 11-18, 2018.

[35] M. Mohamad, N. Rashid, and W. N. W. Mohamad, "The Advantages and Disadvantages of EDictionaries to Enhance Vocabulary Learning of ESL Learners," in Educating for Change, 2017, pp. 315325.

[36] S. S. Cohen, "How teachers conceive their role when working with Generation Z pupils in a technological learning environment," University of Derby, University of Derby, 2016.

[37] K. Moore, C. Jones, and R. S. Frazier, "Engineering Education For Generation Z," Am J Eng Educ, vol. 8, no. 2, p. 111, Dec. 2017.

[38] M. Ozkan and B. Solmaz, "Mobile Addiction of Generation Z and its Effects on their Social Lifes," Procedia - Soc Behav Sci, vol. 205, pp. 92-98, Oct. 2015. 